\title{
Alternatives to land disputes settlement in Indonesia
}

\author{
L. Sumanto* \\ Universitas Trisakti, Jakarta, Indonesia
}

\begin{abstract}
This paper aims to provide an overview of alternatives to land disputes settlement in Indonesia. This research uses doctrinal legal research methods, descriptive, and qualitative data analysis. The legal certainty of land rights is an essential requirement for landowners and it will be realized if there is any legal protection of land ownership. The Minister of Agrarian Affairs and Spatial Planning/Head of the National Land Agency has a very important role in preventing land ownership disputes. Alternative settlement of land ownership disputes is regulated by law. There are 2 types of land dispute settlement: by litigation and non-litigation. Recently, the Ministry of Agrarian Affairs and Spatial Planning/National Land Agency will start using electronic certificates, it is expected that land conflicts will be reduced.
\end{abstract}

Keywords: Indonesia, land disputes settlement, mediation

\section{INTRODUCTION}

Land that is used by anyone and for any purpose must be based on land rights that are protected by law from any arbitrary (Harsono, 2013). Land disputes in conflict affected settings are often considered as a security threat, to be addressed through mediation and strengthening the rule of law (Tajima, 2013). Land disputes can be caused by several factors to show that intervention of another party led to Indonesia's spike in violence (Mamudji, 2017). Law Number 5 of 1960 concerning the Basic Agrarian Law is a legal basis in land issues and legal certainty in Indonesia (Riyadi, 2017). Based on the statement of the Minister of Agrarian Affairs and Spatial Planning/Head of the National Land Agency, Sofyan Jalil, in 2019 there were 8,959 land dispute cases received by the National Land Agency and he had 3,230 land dispute cases that were successfully resolved, consisting of 760 cases included in the K1 settlement criteria, meaning that the Ministry of Agrarian Affairs and Spatial Planning/National Land Agency issued a cancellation decision letter, a rejection decision letter, or a conciliation decision letter between the disputing parties as a result of the mediation of the case concerned; 888 cases included in the K2 settlement criteria, meaning that the settlement of these cases still requires several other requirements and letter of recommendation; 381 cases included in the K3 settlement criteria, meaning that they still require a letter of instruction, as well as a notification letter that the case is not under the authority of the Ministry of Agrarian Affairs and Spatial Planning/National Land Agency. In 2020, the Ministry of Agrarian Affairs and Spatial Planning/National Land Agency is working to resolve 1,201 land dispute cases. The Regulation of the Minister of Agrarian Affairs and Spatial Planning/National Land Agency Number 11 of 2016 concerning Settlement of Land Cases, where it outlines that land disputes can be resolved by related parties through the Ministry of Agrarian Affairs or Court. In 2021, the Ministry of Agrarian Affairs will start using electronic certificates based on the Regulation of the Minister of Agrarian Affairs and Spatial Planning/Head of National Land Agency Number 1 of 2021 regarding Electronic Certificates. The outcome of electronic land registration is in the form of data, information and

${ }^{*}$ Corresponding Author 
electronic documents whereas valid and authentic. The products of this electronic land registration are all stored in the Electronic System Database. With the validity of electronic certificates, it is expected that land conflicts will be reduced.

\section{METHODS}

This research uses normative doctrinal research methods that focuses on the formulation of laws. Doctrinal research is therefore concerned with the discovery and development of legal doctrines for publication in textbooks or journal articles (Chynoweth, 2008). The method in this research is the statute approach (Hutchinson, 2002). The research specifications are descriptive, namely describing, analyzing, and concluding problems that are the object of research concerning land dispute settlements. Library research has a characteristic that identifies various sources that provide factual information or expert opinions on research questions (George, 2008). The legal material reviewed and analyzed in this research uses secondary data consisting of legislation, books, legal journals, and newspapers (Denzin \& Yvonna, 1994).

\section{RESULTS AND DISCUSSION}

\subsection{Land dispute settlement by the ministry of agrarian affairs and spatial planning/national land agency}

A land registration system with a negative publication system tends to lead to the possibility of land disputes (Ginting, 2016). The Regulation of Minister of Agrarian Affairs and Spatial Planning/Head of the National Land Agency Number 11 of 2016 concerning Settlement of Land Cases is regulated land cases can be differentiated between disputes, conflicts, or land cases. Land disputes are disputes over land between individuals, legal entities, or institutions that do not have a broad impact. Land conflict is a land dispute between individuals, groups, organizations, legal entities, or institutions that have a broad impact. Land cases are land disputes which are handled and resolved through judicial institutions. Every land dispute arises because of several very dominant factors, namely (a) incomplete regulations, (b) non-compliance with regulations, (c) unresponsive officials, (d) incomplete and inaccurate land data, (e) incorrect land data, (f) limited human resources, (g) incorrect land transaction, (h) cheating applicants, (i) overlapping dispute resolution authority from other institutions (Sumardjono \& Maria, 2008). Alternative Dispute Resolution is a type of procedure voluntarily used by parties in dispute to resolve their issues (Sullivan \& Solomou, 2011). Law Number 30 of 1999 regarding Alternative Dispute Resolution and Arbitration regulates dispute resolution options through deliberation of the disputing parties. The definition of Alternative Dispute Resolution is a settlement of disputes or differences of opinion through a procedure agreed by the parties, a settlement outside court through deliberation, negotiation, mediation, conciliation, or expert judgment (Usman, 2013). The administrative process and the recording of the handling of complaints are distinguished for the two reporting mechanisms namely initiatives from the Ministry of Agrarian Affairs and complaints from the public.

Mediation is a method of resolving disputes and conflicts through a negotiation process with the assistance of a mediator to get an agreement between the parties. Settlement through mediation will be simple and deliberative between the parties concerned and the result will be a win-win solution or to the advantages of both parties. The mediator, as a third party helps related parties find the right solution without coercion. The type of mediator used by the Ministry of Agrarian Affairs and Spatial Planning/National Land Agency is an Authoritative Mediator, being an official who has competence and knowledge of the disputes to be handled (Arwana \& Arifin, 2019). Mediator is neutral and independent and cannot be influenced by other parties (Yazici, 2016). The decision-making rests with the parties themselves. The mediator's role includes assisting disputants in defining and clarifying issues, reducing obstacles to communication, exploring solutions and 
reaching a mutually satisfactory agreement. Conflict resolution is managed by one or several expert advisors or through a mediator.

The findings and complaints were analyzed to find out whether the land cases were under the authority of the ministry. Disputes or conflicts which are within the authority of the Ministry of Agrarian Affairs and Spatial Planning/Land National Agency, related to errors procedures in: (a) the measurement, mapping and area calculation processes, (b) the process of registering or recognizing the rights to former customary land, (c) the process of determining and/or registering land rights, (d) the determination of abandoned land, (e) overlapping rights or certificates of land rights where one of the reasons for the rights is wrong, (f) the process of maintaining land registration data, $(\mathrm{g})$ the process of issuing replacement certificates, (h) to providing information on land data, (i) the licensing process, $(\mathrm{j})$ misuse of space utilization, and (k) other errors in the application of statutory regulations. Other than matters related to the dispute or conflict then the Ministry of Agrarian Affairs and Spatial Planning/Land National Agency is not authorized to handle land cases. However, this Ministry can take the initiative to facilitate a dispute or conflict resolution by mediation. Mediation in this regulation is also carried out for types of disputes or conflicts either within the authority of the ministry or those that are not within his authority. Settlement through mediation can be taken if the parties agree to negotiate on the principle of deliberation to reach a consensus for the benefit of all parties. If one of the parties refuses, the settlement can be resolved through the court instead. Technically, mediation is carried out for a maximum of thirty days and the Ministry of Agrarian Affairs and Spatial Planning/Land National Agency acts as the mediator from the Provincial Land Office or the Regency/Municipal Land Office. If the mediation agreement is made, furthermore, a reconciliation agreement is made based on the Mediation Minutes which is legally binding on the parties.

Furthermore, the reconciliation agreement shall be registered at the Registrar's Office of the local District Court to obtain binding legal force. Mediation is deemed canceled, if after being properly invited three times, the parties or one of the disputing parties is not present. Background of the land case is due to a lawsuit/complaint/objection from individuals or legal entities to certificate of title which stipulated by the officials within the National Land Agency, and it is deemed to be detrimental to their land rights (Sumanto, 2008). Based on the lawsuit, the public wants to immediately obtain an administrative settlement called correction from the authorized official. The head of the National Land Agency has the authority to correct the certificate of title. Once he receives complaints from individuals or legal entities, he will aim to resolve the problem by conducting research and collecting data. Based on the results of the research, it can be concluded temporarily whether the complaint can be processed further or not. If the data submitted to the National Land Agency is still incomplete, the National Land Agency will ask for explanation, data, advice from the Head of Provincial Land Office and the Head of Regency/Municipal Land Office where the disputed land is located. When the data is complete, there will be a re-checking of the proposed matter which includes aspects of procedure, authority and legal application. In order to ensure that the interests of the community are protected by law, if deemed necessary, the Head of Regency/Municipal Land Office can block disputed land. This policy is regulated in Regulation of the Minister of Agrarian Affairs and Spatial Planning/Head of the National Agrarian Agency Number 13 of 2017 concerning Procedures for Blocking and Confiscation.

In practice, an individual or legal entity whose interests have been harmed can submit an application blocking a certificate of land title to the Head of the National Land Agency or through the Head of the Regency/Municipal Land Office to be forwarded to the Head of Provincial Land Office where the land is concerned. The Head of Provincial Land Offices and the Head of Regency/Municipal Land Offices can only determine the status quo or block certificates of land title after there is a stipulation of collateral confiscation from the Court. Land cases which are submitted to the National Land Agency to be resolved, the first alternative of settlement for the disputing parties is through mediation where the National Land Agency acts as a mediator. Where land disputes have reached an agreement, written evidence must be made in a notary deed and minutes of meeting. If after examination it turns out that a certificate of title is correct according to the law and in accordance with the applicable procedures, the Head of National Land Agency can issue a decision to reject 
claims of a third-party objection to the certificate of title issued. Furthermore, he also can issue a decision rejecting the objection from any concerned third party. As a consequence of the refusal, a certificate of title which had been issued will still be valid. However, notwithstanding to a judge's definite legally binding decision, the Head of Regency/Municipal Land Office through the Head of the Provincial Land Office can propose a decision to cancel a certificate of title to the National Land Agency. The head of the National Land Agency can only cancel a certificate of title if there is a legal error or administrative error in its issuance. The authority to cancel a certificate of title is under the Head of the National Land Agency, including the policies to be taken regarding a judge's decision that cannot be implemented.

Land dispute resolution can also be reached through conciliation. Conciliation is the resolution of conflicts, including land conflicts, mediated by one or more neutral conciliators chosen by agreement of the parties (Priyatna, 2002). The conciliator is obliged to provide advice to the disputing parties to resolve the dispute and he must be registered with the Regency/Municipal Land Office (Winarta, 2013). The conciliator must be able to settle the dispute no later than thirty days after receiving a request for resolution. At the first of the settlement, the conciliator is required to reconcile the parties. If a reconciliation agreement occurs, then a joint agreement is made and then registered in the court where the agreement is made. If one party does not exist to the agreement, the other party may submit an application for execution in the court where the collective agreement was lodged (Haspada, 2019).

\subsection{Land dispute settlement by the court}

In principle, if no agreement is reached through mediation between the disputing parties, as mediated by the National Land Agency, the dispute settlement must be through a court. According to the Regulation of the Supreme Court of the Republic of Indonesia Number 1 of 2016, all civil disputes (including land disputes) which are submitted to the District Court shall seek a settlement through reconciliation with the assistance of a mediator first. The first stage is the pre-mediation process stage: A judge will oblige the parties to mutually mediate problems within 7 (seven) days for parties that are domiciled in the same city/regency as the District Court, or 14 (fourteen) days if one of the parties is domiciled in a different city/regency than the District Court. During mediation process in court, the parties have the right to choose a mediator from the options: (a) judges who are not case examiners, (b) lawyer or legal academics, (c) non-legal profession, (d) judge of examining this case, or (e) a combination thereof, if there are more than one mediator in the mediation process, the mediator's duties are determined and agreed upon by the mediators themselves.

We should choose an appropriate mediator, considering experience, credibility, skills, cost, etc. The second stage is the mediation process stage: The mediator will summon the parties to mediate twice. If after two summons one of the parties or both are absent, then the mediation is deemed to have failed. In the event that mediation is deemed to have failed, the mediator will make a recommendation regarding the failure of mediation to the Panel of Judges handling the case, which will become a consideration for the judge in deciding the case. If the parties are present and actively carry out reconciliation efforts, the mediation process will last no more than forty days. Nevertheless, the mediation period may be extended for a period of fourteen days based on the agreement of the parties. If deemed necessary, mediation can be carried out using communication media. The mediation process must be carried out in good faith. One party may declare withdrawal from the mediation process if the other party is proven to have mediated in bad faith. If the mediation results in a reconciliation agreement, the parties, assisted by the mediator, must formulate an agreement reached and signed by the parties and mediator. Before the parties sign the reconciliation agreement or mediation agreement, the mediator examines the material of the reconciliation agreement to avoid an agreement that violates law, or cannot be enforced or harms any third parties. The parties then return to the judge to notify the reconciliation agreement and propose to the judge that the reconciliation agreement be made in the form of a reconciliation deed which is final and binding. If the settlement through mediation in court between the parties is not reached, the settlement of land disputes must be carried out through court channels. 
The next stage is evidentiary hearing by reading the plaintiff's claim and response from the defendant. The plaintiff and defendant will argue each other's answers, and the trial will enter the evidentiary stage. The evidentiary process is time consuming and an arduous journey given that all written evidence, testimony from witnesses and expert witnesses, as well as various other evidences must be presented and examined in court. During the trial process, reconciliation is still a possibility given the arduous process.

\section{CONCLUSIONS}

Dispute resolution can be carried out through two processes: litigation and non-litigation. Litigation is the resolution of legal issues through the courts. Whereas non-litigation means resolving legal matters outside the court. This non-litigation path is known as Alternative Dispute Resolution. A litigation process in court tends to have a longer time frame due to procedural and administrative issues, and also costly for the disputing parties. On the other hand, a non-litigation process outside court where trial process and decisions are not published, the confidentiality of the disputes of the parties is more guaranteed, therefore settlement of dispute is faster, resulting in a win-win solution agreement. The Ministry of Agrarian Affairs and Spatial Planning/National Land Agency will start using electronic certificates, it is expected that land conflicts will be reduced.

\section{REFERENCES}

Arwana, Y.C. \& Arifin, R. 2019. Mediation on land disputes settlement on promoting human rights fulfillment. Jambura Law Review 1(2): 212-236.

Chynoweth. 2008. Advanced research methods in the built environment. United Kingdom: Wiley Blackwell.

Denzin, N.K. \& Yvonna, S. L. 1994. Handbook of qualitative research. London: Thousand Oaks, Sage Publications.

George, M.W. 2008. The elements of library research: What every student needs to know. New Jersey: Princeton University.

Ginting, D. 2016. Land registration in information technology perspective a basis of basic agrarian law in indonesia. International Journal of Scientific \& Technology Research 5(5): 184-186.

Harsono, B. 2013. Indonesian land law. Jakarta: Trisakti University Publisher.

Haspada, D. 2019. Arbitration as an alternative dispute resolution for land disputes based on Indonesian regulation. International Journal of Innovation, Creativity and Change 8(5): 294-305.

Hutchinson, T. 2002. Researching and writing in law. New South Wales: Published Lawbook Co.

Mamudji, S. 2017. Mediation as an alternative dispute resolution in out of court. Law and Development Journal 34(3): 194-209.

Priyatna, A. 2002. Arbitration \& alternative dispute resolution. Jakarta: Fikahati Aneska.

Riyadi, B.S. 2017. Law of agrarian and resolution effort: A claim of eigendom verponding land. International Journal of Law 3(3): 80-88.

Sullivan, E. \& Solomou, A. 2011. Alternative dispute resolution in land use disputes - two continents and two approaches. The Urban Lawyer 43(4): 1035-1059.

Sumanto, L. 2008. Mediation: The alternative of land dispute resolution in Indonesia. Asia Pacific Mediation Forum Conference, International Islamic University Malaysia 8.

Sumardjono, and Maria, S.W. 2008. Mediation of land disputes, potential application of alternative dispute resolution (adr) in the land sector. Jakarta: Kompas Gramedia.

Tajima, Y. 2013. The institutional basis of intercommunal order: Evidence from Indonesia's democratic transition. American Journal of Political Science, 57: 104-119.

Usman, R. 2013. Alternative dispute resolution in out of court. Bandung: PT Citra Aditya Bakti,

Winarta, F.H. 2013. Legal dispute resolution. Jakarta: Sinar Grafika.

Yazici, H. 2016. The art of opera in Turkey within the scope of culture-art policies. International Journal of Humanities, Arts and Social Sciences 2(5): 159-164. 